
Joan Miquel
Vol. VII
comparative cinema

Gual

\title{
Ruins. A visual motif of the Spanish real estate crisis
}

Throughout history, ruins have represented the traces of fallen empires and post-battle landscapes. Progressively, with the urbanization of the world, there are more and more ruins which are the result of rapid construction that leaves visible traces: viewed from the air they resemble metastases, or scars. Such ruins become garbage, remains that are derived from intensive exploitation of the territory based on the rationale of the accumulation of capital, rather than the interests of the general public or environmental sustainability. Many television reports, movies and photographic works have addressed the visual motif of ruins in the context of the crisis that began in 2008. The aim of this paper is to contribute to the ongoing reflection on the issue, by examining various nonfiction titles that were published after the Auken Report (2009). My objective is to show the abundance of audiovisual representations which, apart from the testimonies, have served as criticisms of the Spanish development model from an environmental perspective and the marked inequality that this model generates.

Keywords

RUINS

VISUAL MOTIF

REAL ESTATE CRISIS

ENVIRONMENTAL DESTRUCTION

MILITANCY

CINEMA

PHOTOGRAPHY

SPAIN

Date of reception: 09/04/2018

Date of acceptance: 28/08/2018

Joan Miquel Gual Associate Professor at Universitat Oberta de Catalunya. He teaches History of Cinema and Arts on Screen. Doctor in Theory, Analysis and Film Documentation from Universitat Pompeu Fabra and Master's Degree in Theory and Practice of Creative Documentary from Universitat Autònoma de Barcelona. He is also a housing activist, he has participated in social movements such as VdeVivienda and is part of the housing cooperative La Borda SCCL, which has recently been set up in Can Batlló. He is currently investigating the image of the Spanish real estate bubble in film, photography, and literature, and is preparing a book on the subject. 
Ruins and landscape. A vivid debate

"All they talk about on the radio every morning is how the building bubble has burst, about the huge national debt, risk premiums, savings banks going bust and the need to cut public spending and reform the country's labor laws. The crisis. Unemployment in Spain stands at more than twenty percent and this could rise to twenty-three or twenty-four next year. A lot of immigrants live on unemployment benefits [...] Five or six years ago, everyone was working. The whole area was one big building site. It seemed that not an inch of land would be left unpaved; now it looks rather like an abandoned battlefield, or a territory under armistice: sites overgrown with weeds, orange groves transformed into building lots; neglected, withered orchards; walls enclosing nothing at all"

Rafael Chirbes, En la orilla (On the

Edge)

The subject of this research is the representation of the ruins that emerged on the Spanish landscape after the real estate crisis started in 2008. These ruins exist because of excesses in the construction sector in Spain where, at its peak, more homes were built than in Germany, Italy and France combined. Specifically in the year 2005, more than 800,000 homes were started without there being enough demand to buy them.

Beyond this excessive construction, the crash also happened because of an interlacing of public policies and the interests of the economic system that encouraged the massive purchase of homes by taking out mortgages. When the building cycle stopped, a lot of families were left unemployed and weren't able to pay back their bank loans. As a result, the main banks and credit unions went bankrupt and the Spanish government came to their rescue, following the dictates of recovery imposed by the Troika (European Commission, the European Central Bank and the International Monetary Fund).

The introduction of the novel En la orilla (On the Edge) was written during one of the most difficult years in the Spanish economic crisis (2013), and it condenses a great deal of the iconography on which this article will be focusing. The idea of presenting the urban landscape metaphorically, like the posterior remains of a battle, will be linked, in the first section (Ruins of a war with no dead), to the human landscape that a historic moment has created: the ones who have been broken by the crisis or defeated in the housing war with no dead.

In order to approach the meaning of this nonfictional iconography, relative to the historical present, the following statement is important:

"The spectacle of ruin, since World War I, does not show any memory of the past, nor any reference to history, or any contemplation of what has been lost. The ruin is, from this moment on, a ruin of the present, an immediate present that we have in front of us, and does not refer to anything other than itself [...] Hence the realism with which the ruin is represented, and there can be no means of expression more effective or eloquent than that of photography, film and documentary to show the realism that this ruined reality demands" (MARÍ, 2005: 20).

To connect the idea presented by Marí to the current Spanish context, we should bear in mind the concept of "speculative ruins", created by Kathy Korcheck in relation to the photographic depiction of the Spanish crisis presented in the works of Markel Redondo, Julia Schulz-Dornburg 
and Cadeslasverdes: “'Speculative ruins' speak to the notion of market 'speculation' as well as reference Guy Debord's conceptualization of the 'spectacle', 'the perfect image of the ruling economic order' whereby 'ends are nothing and development is all'" (2015: 92). The ruins of the crisis, according to Korcheck's point of view, produce an anti-nostalgic vision in those who look at them, and which is used to articulate a critique of capitalism and the society of the spectacle that legitimizes it.

On the other hand, the ruins in question can also be defined as Ballardian ruins ${ }^{1}$, i.e., as architectonic waste deriving from construction hubris. That being said, in no way is it about evoking (like in science fiction) a hypothetical dystopian future that is yet to come, as in the ruins dreamt of by the cinema that has been presented by Andrés Hispano (2005:173-183), but instead about pointing to a disturbing present:

"The ruin leads us to reflect on the fragility of the contemporary world. A daily fragility, recurring throughout history, but which has now acquired a dimension that hadn't been considered before. A cultural, energetic, economic, demographic and biological fragility" (MARÍ, 2005: 21).

One academic benchmark in film iconography that we should take into consideration is Motivos visuales del cine ("Visual motifs of cinema") (BALLó and BERGALA, 2016), a taxonomic reflection by many different voices that is based upon a very clear statement: "We hope that this book, written by 'two countries' (as we say of a piece of music that is played by 'four hands') is able to spark the emergence of a true theory of motif in cinema" (2016:16). Although no theory of visual motif in cinema exists, the text La cicatriz ("The scar") (LEPASTIER, 2016: 353-355) has proven very useful for this article, and mainly for its second section: Dystopian ruins. Real estate corpses as critique and militancy.

Apart from cinema, the spread of the nonfiction iconography that interests me has been heavily inspired by initiatives linked to the environmental movement, using social media. The groups Terra Ferida, Nación Rotonda and Basurama have devoted enormous effort to taking pictures of the physiognomy of the bursting of the bubble: real estate corpses all around the country, metaphorical unfinished roads to nowhere, territorial epidermis seen from the air, resembling tumors, advanced metastases, knife cuts. All of this has consolidated a critical memeology that has led to a new form of militant and protest intervention, and which takes ruins as its main subject.

In contrast, economic and political power has created opposing readings of the same context. From the perspective of the different governments that have had to manage the real estate crisis, the ruins simply exemplify a temporary moment, which can be overcome by means of suitable public policies oriented towards selling off the available housing and infrastructure stocks to the highest bidder, and as fast as possible. That is what the SAREB or bad bank ${ }^{2}$ is for. Within this ideological framework, the case of Seseña would be seen as paradigmatic: from the icon of crisis and excess to the land where many families live today. From ruins to a symbol of recovery.

This interpretation of the crisis, and of the ruins that derive from it, as if it were an entirely surmountable transition and effect, will also be contrasted with other perspectives, like the Auken Report: approved by the European Parliament in 2009, it questioned the Spanish development model and proposed a series of 


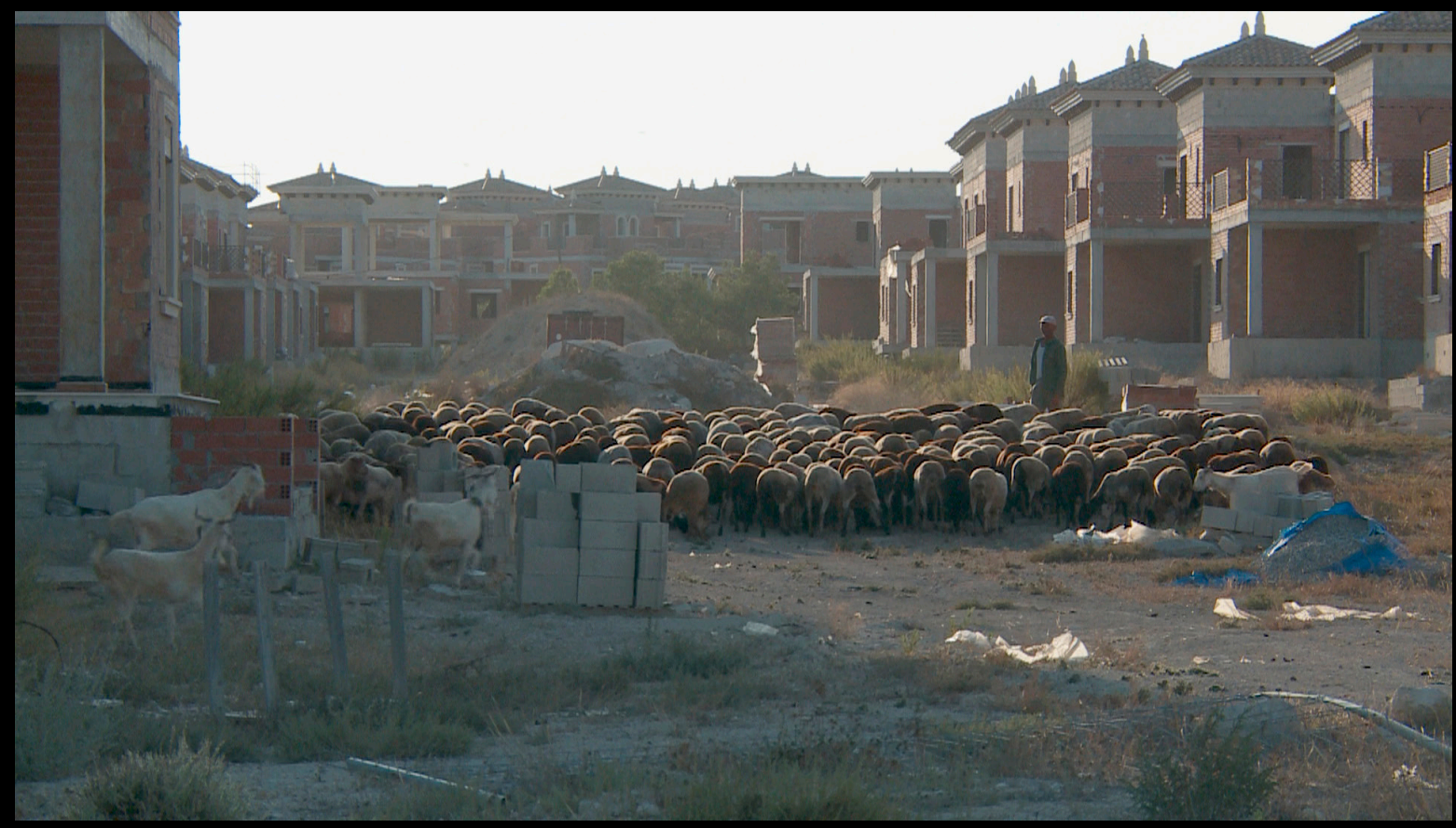

Houses for All (Casas para todos, Gereon Wetzel, 2013)

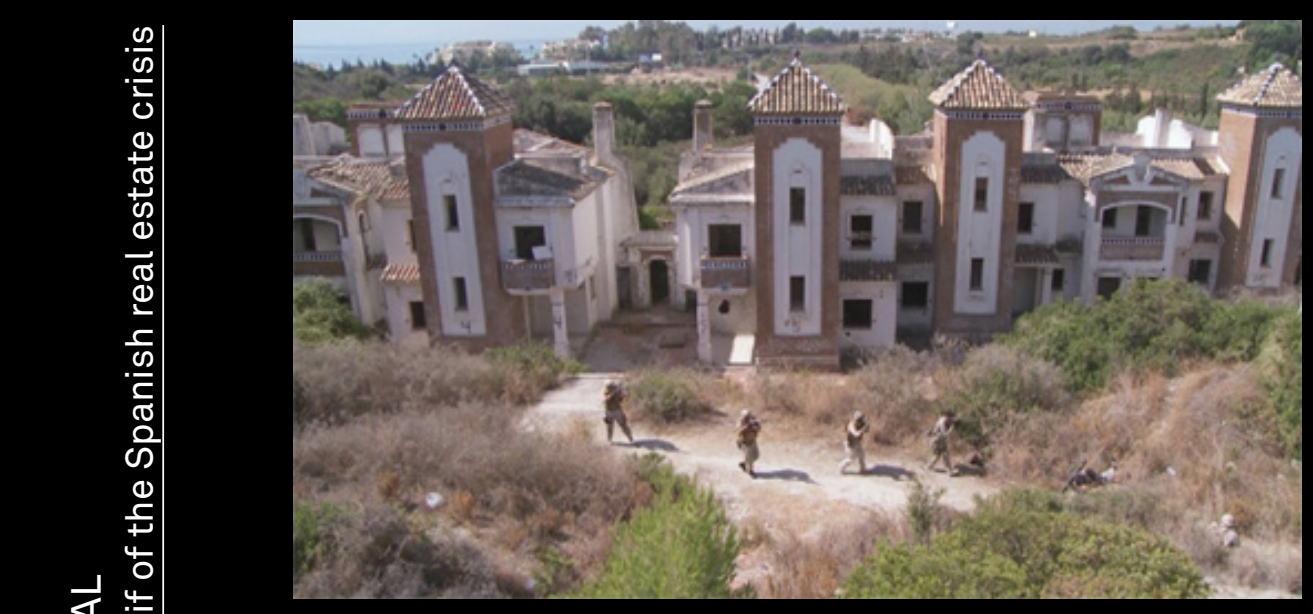

Houses for All (Casas para todos, Gereon Wetzel, 2013) 
measures to reverse the situation, though to this day, no policies regarding substantial reorientation in favor of the right to housing and the preservation of the environment have been applied.

Finally, the aforementioned visual motif will be framed within the Benjaminian ideas of the ruins of history. For the German author, ruins are synonymous with human catastrophe from the past, opposing evolution towards the future. Ruins summarize visually the critique of progress formulated by Benjamin in his ninth thesis "on the concept of history". This is presented using the allegory of a storm that blows in from Paradise, pushing the angel of history against its will, while he powerlessly contemplates the disaster of the ruins piling up in front of him. The wind "[...] irresistibly propels him into the future, to which his back is turned, while the pile of debris before him grows skyward. What we call progress is this storm" (BENJAMIN in LÖWY, 2005: 62). In the Spanish crisis, the angel of history flies over "Ballardian" landscapes.

\section{Ruins of a war with no dead}

Empty buildings are the main feature of real estate bankruptcy, but it is not an unchanging feature. We can find cases in which these building are reused to be lived in, and others in which the ruin is found within the human figuration of those displaced abroad, or the victims of gentrification.

The Basurama ("Trasharama") project $6000 \mathrm{~km}$ invites us to "reflect on the metabolism of cities, by making visible certain landscape-territories related to the production, consumption, and residue of materials and energy" (BASURAMA, 2011). 6,000 kilometers represents the journey through the real estate ruins located all around the peninsula, as well as the kilometers of freeway that PEIT (the Spanish acronym for Strategic Plan of Transport Infrastructure) aims to build in Spain before 2020. The subtitle of the project links with Chirbes' aforementioned fragment: "Landscape after the battle".

$6000 \mathrm{~km}$ brings together different exhibition projects, a collaborative map and a digital book. The latter shows thirty-one locations. Each of them is presented in the form of a file card that consists of a photograph, a brief description of the building project and its state of abandonment, its geographic situation, the dimensions to scale and an expressive quote from texts from different sources, depending on the case - a novel, texts on urban geography, movie dialogues, etc. Altogether, it is a work that can be described as Benjaminian, given the form and political aim that it pursues. In formal terms, it presents an aesthetic of the quote and the reference, similar to the chapters of The Arcades Project (BENJAMIN, 2013). The sum of fragments and images seeks to produce a particular political effect: to articulate a visual critique that demonstrates the failure of the Spanish development model.

The devastation of the Spanish territory to which $6000 \mathrm{~km}$ refers has led to such a profound transformation of the landscape that we can adapt to the present that famous quote by Strabo, the Greek historian and geographer who declared that in Roman times, a squirrel could cross the peninsula from north to south without having to descend from the trees. Nowadays, the squirrel could cross from north to south without touching the ground, jumping from ruin to ruin.

We only need to look at file card number eight to find an expressive example of $6000 \mathrm{~km}$ : "Abandoned residential area in Llanos de Velerín" (Malaga), made up of thirty-five homes distributed across 2.4 hectares. This place also appears in the nonfiction 
feature film Houses for All (Casas para todos, Gereon Wetzel, 2013), which shows how, surprisingly, the empty properties have been reused by the Spanish army. Wetzel shows the scenario (which the artistic group presents as a landscape after the battle) turned into a training camp where soldiers rehearse defense and ambush techniques. In this way, the metaphor of the wartime landscape becomes almost literal.

Futures Market (Mercado de futuros, Mercedes Álvarez, 2011) enables us to delve into the iconography that has been posited up to now. This full-length nonfiction film alternates scenes of the demolition of an old building with sequences like the one in which we hear a great show business guru quoting Rothschild in an academic lecture: "The great fortunes pile up while bombs drop on the port, not when the violins play in the parlors". In this way, the film expresses the notion of a crisis which is viewed, from the point of view of economic power, as a business opportunity, that is to say an entrepreneurial field in which to apply Schumpeterian creative destruction, and a speculative possibility that is filled with offers, in a context (the one in the film's present) in which real estate prices in Spain had fallen drastically.

Though Futures Market is clear about who the winners of the battle are, the ruins show that many more have been defeated. To give just one example, we should mention the environmental movement, which we will discuss in detail in the following section. Here we will talk about, firstly, the iconography of the reuse of empty homes, the conversion of real estate skeletons into living machines, by people and families who have been evicted from their homes.

In 2017, the website Idealista published the following headline:
"The burden of housing: 1.36 million of empty homes are still on sale all around Spain" (IDEALISTA EDITORIAL, 2017). The news report explained that 348,000 properties had come onto the market since 2010, the year in which the number of empty houses was at its peak. It went on to say that between 2012 and 2015, 177,900 evictions took place (data from the Bank of Spain), which, together with the other 244,000 that happened between 2008 and 2011, according to the Platform for People Affected by Mortgages (or PAH, using the Spanish acronym), rise to a total of over 400,000 families that have lost their homes between 2008 and 2015.

In this context, documentaries like La Plataforma ("The Platform" by Jon Herranz, 2012) and Si se puede. Seven Days at PAH Barcelona (Sí se puede. Siete días en la PAH de Barcelona, Pau Faus, 2014) show the process of self-organization of one of the most influential social movements in democratic Spain. One of the bestknown slogans of PAH is "It makes no sense: people with no homes, and homes with no people!"

Hundreds of buildings squatted and marked with the sign "PAH Social Work", manuals that explain to ordinary people how to squat a property, and interactive maps of empty homes generated by La Plataforma are all part of this iconography of popular recovery of ruins to implement the right to housing, which is included in article 47 of the Constitution ${ }^{3}$. This iconography is present in Wetzel's aforementioned film, which shows the experience of Corrala Utopía, a building occupied by poor Andalusian families.

Secondly, the impoverishment produced by the crisis grabbed television and media attention in its most intensive years, both domestically and internationally. Of the great number of reports on the subject that we could mention, we would point to The 
Great Spanish Crash (BBC, 2012). This focuses on Valencia, and explains how the general economic crash took place. One of the examples chosen to show the effects of the crisis is Sant Miquel de Salines, a small town which is similar to Chirbes' Misent ${ }^{4}$ due to lots of abandoned construction works, where there used to be forests of cranes working at full capacity.

As a consequence of the construction paralysis, the feature shows the program of a neighborhood association aimed at helping the longterm unemployed to find work. The association also provides a food bank for those most in need, where essential goods can be obtained, such as milk and sugar. To complete this panorama of impoverishment, the reporter interviews jobless young people, work exiles in other countries. In this case, the ruins are synonymous of economic exile, enforced emigration in search of a better future abroad because of a lack of opportunities, an issue that is also addressed in documentaries like Spanish Exile (Españoles en el exilio, Rubén Hornillo, 2015) and In a Foreign Land (En tierra extraña, Icíar Bollaín, 2014).

Thirdly, another form of iconography linked to the real estate cycle needs to be mentioned: the ruins of gentrification, a process that cannot be separated from the human figure of the displaced person, those who are driven out by the urban reform and city model. Work in Progress (En construcción, José Luís Guerín, 2001) was already a precrisis example of social replacement or gentrification in the Barcelona neighborhood of Raval, after a major urban planning transformation. Since then, there have been so many people forced to abandon certain neighborhoods that Left Hand Rotation (a Madrid collective) has proposed the creation of the collaborative archive El museo de los desplazados ("The museum of the displaced"). This archive documents - based on individual contributions - the cases of expulsion from neighborhoods that happen in many places in the world, though a great deal of them take place in Spain.

As an example of the documentation "work in progress", I will mention here the photographic work Site Consumption - one of the three that are included in Alejandro S. Garrido's project about Cabanyal (Valencia). It shows many ruins and it is described as follows by the author:

"A visual project based on the destruction of Cabanyal in Valencia. The project revolves around how the production of a city-brand, the new Valencia, involves the destruction of the social fabric, the cultural heritage and the supplanting of all preexisting identity or discursive heterogeneity" (GARRIDO, 2011).

Despite this one-dimensional vision, we should also consider other, more dialectical stories about the same context, views such as the one proposed in Abril al Cabanyal ("April at Cabanyal" by Sergio Tarín, 2013), which describes the first 15 years of resistance by the Salvem El Cabanyal ("Let's Save El Cabanyal") platform, and the more recent one, Cabanyal any zero ("Cabanyal Year Zero", by Frederic Presmann, 2018), dealing with the mobilizations, uneasiness, milestones and hopes of the existing population of the Valencian neighborhood.

In closing this section, I should mention that in wartime, suspension of rights, poverty, exile and the displacement of population all occur. These situations have also taken place in the Spanish financial-housing crisis which, based on the iconography of the abundant ruins, can be defined as a kind of war with no dead. The resulting urban planning landscape is completely inseparable from the human landscape. 
Both, in succession, can help us to develop and elaborate upon the constructive comparison between war and crisis, as well as to highlight a map of the ones ruined or defeated by the struggle, and which makes quite clear the deep inequality that exists. For this reason (and others that we will examine further on), the landscape of the crisis is, in a Benjaminian sense, a "document of culture" that is also a "document of barbarism".

\section{Dystopian ruins. Real estate corpses as a critique and militancy}

The Auken Report in images

In 2007, the then-president of the Spanish Government José Luís Rodríguez Zapatero claimed: "Spain is safe from the economic crisis" (EL PAís, 2007). However, The Economist had warned two years before that "This boom is unprecedented in terms of both the number of countries involved and the record size of house-price gains [...] The global housing boom is the biggest financial bubble in history. The bigger the boom, the bigger the eventual burst" . Voices such as ecologist Ramón Fernández Durán (FERNÁNDEZ DURÁN, 2006) and the professor in Real Estate Economics for the University of Montreal, Ricard Vergés - interviewed in the documentary €uroestafa (Guillermo Cruz, 2014) - also warned about the burst that was to come.

In 2008, cranes stopped moving because of the crisis. At that time, the Spanish landscape stopped being synonymous of an "economic miracle", as President José María Aznar had defined it (CALVO ROY, 1997), to become a landscape of ruins and abandonment. The Building (Edificio España, Víctor Moreno, 2012) captures very expressively the effects of this paralysis. The title works as a metaphor for the whole country: the iconic skyscraper of Madrid is used to evoke the story of the peak and fall of the real estate cycle, without forgetting the evictions and mass unemployment that went with it.

A year before the documentary was released, "Nobody represents us" had been one of the main slogans of the $15 \mathrm{M}$ people's movement, in addition to "PSOE-PP, both are the same shit". On the Internet and in the town squares the concept \#PPSOE was created, to highlight the idea that the two main parties were becoming more and more indistinguishable because of the policies they applied in a similar, complicit way.

Among the reasons for this lack of differentiation by the people was the reaction by both political parties to the devastating Auken Report. This report dealt with "The impact of the extensive urbanization in Spain on individual rights of European citizens, on the environment and on the application of EU law, based upon petitions received" (AUKEN, 2009). The text was written based on complaints of aggression in the territory coming essentially from the ecologist movement. It was overwhelmingly approved by the MEPs, albeit with a dissenting vote from the Partido Popular (People's Party) and the abstention of the PSOE (Spanish Socialist Worker's Party). The report called for the freezing of EU funds if the urbanization abuses in Spain weren't brought to an end. The points that came in for the greatest criticism in the report were: 1 . Biased land inspection;

2. Citizens becoming victims of the economy; 3 . Good faith vs. few scruples; 4. The islands, annihilated by speculation; 5 . Plunder as a model; 6 . Illegal houses continued to be sold; 7. The coasts law virtually ignored; 8 . Arbitrary demolitions; 9 . All the official administrations judged to be guilty; 10. Court sentences not being upheld (LEAL, 2009). 


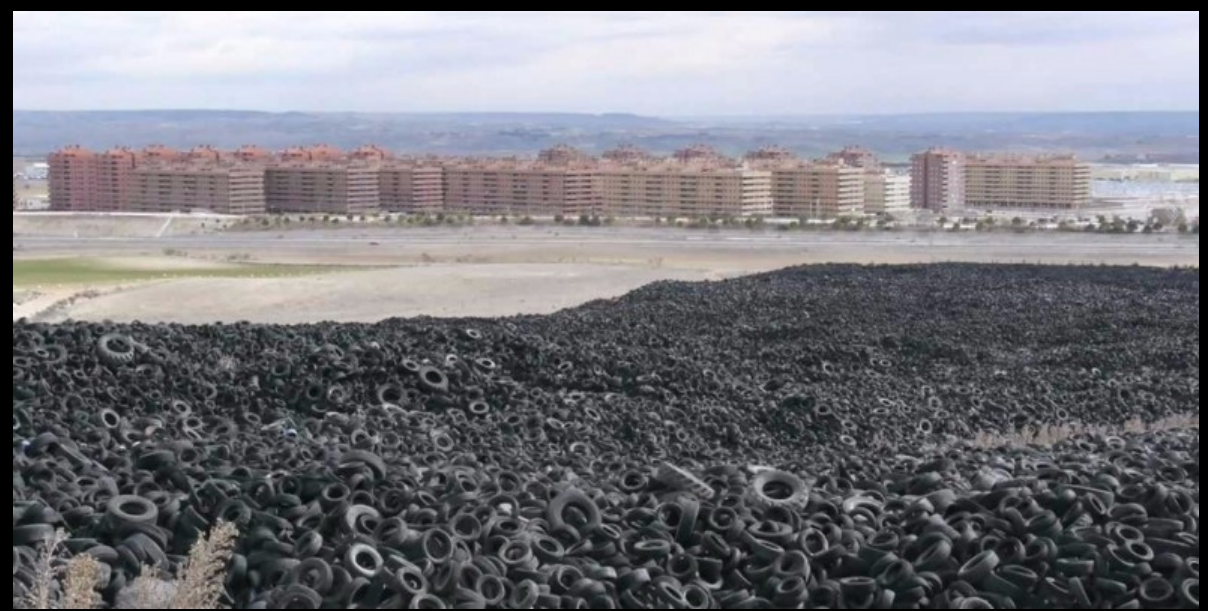

Seseña

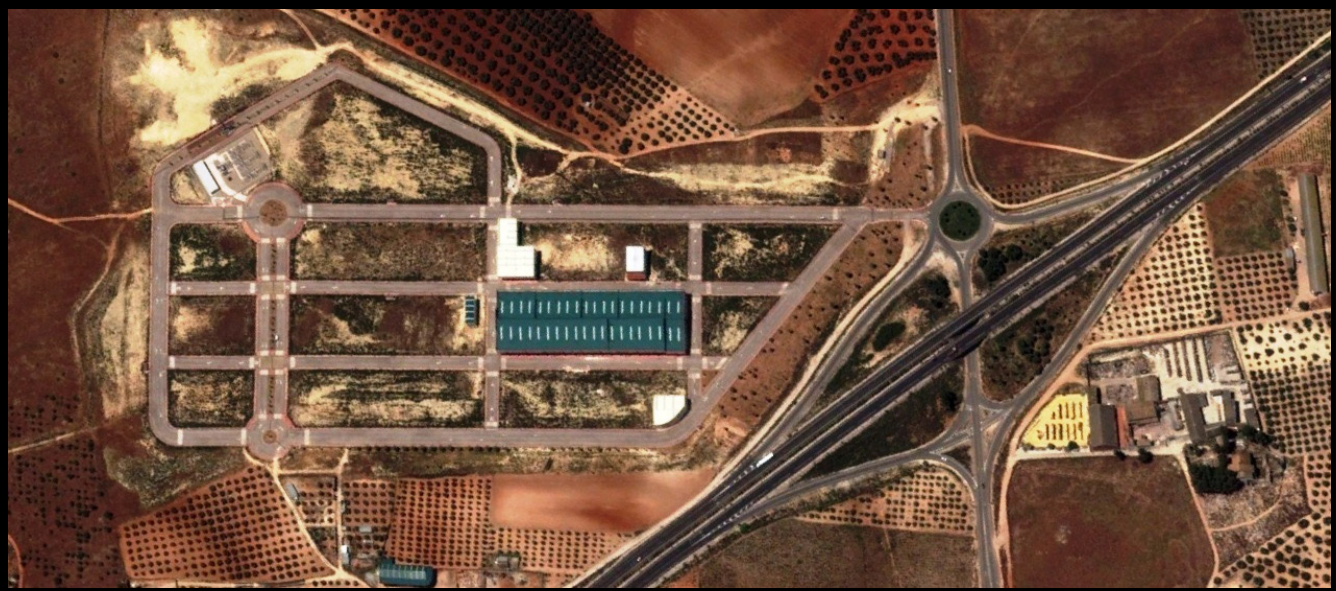

Nación Rotonda
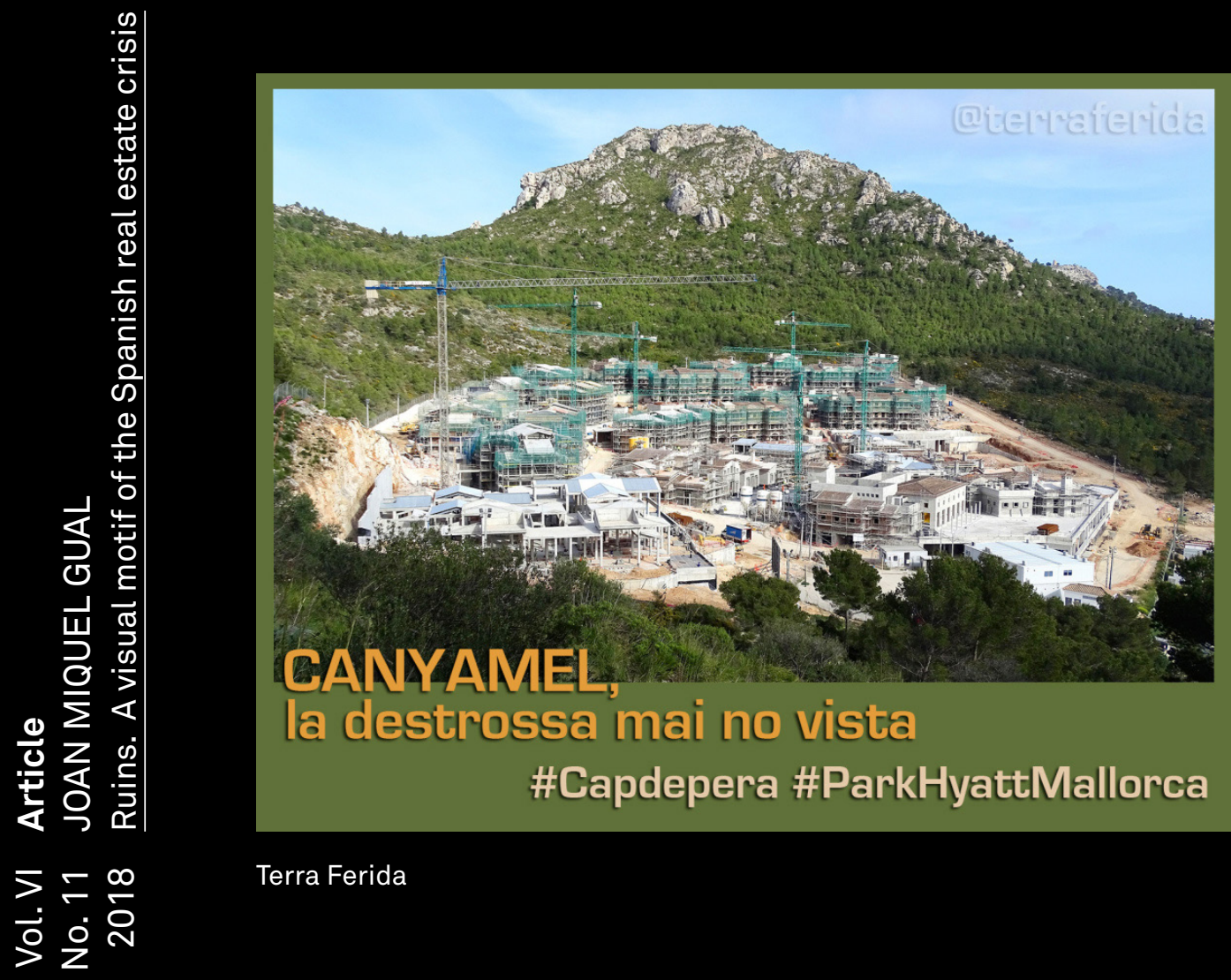

\#Capdepera \#ParkHyattMallorca

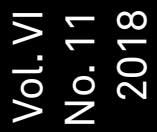


The ways in which the situation decried by the report was expressed upon the landscape came in for an interesting, pioneering scrutiny in the book Ruinas modernas ("Modern Ruins") (SCHULTZ-DORNBURG, 2012). Topografía del lucro ("A Topography of Lucre") is its expressive subtitle. In total, Schultz shows in great detail 25 building projects brought to a halt, spread out across the peninsula and located using Google Maps. Attached to the photographs, which are either aerial or over the land, we find a brief chronological explanation of the processing, planning, construction and abandonment of all the projects. There is one thing that all the cases have in common: the planning, apart from one project, took place in the years of steady growth from 1993 to 2007. Also, in all but one of the constructions, they were abandoned between 2008 and 2011. Both time frames coincide with the real estate cycle and its crisis, respectively.

On the other hand, Hispanic capitalism has created its own myths regarding recovery. The main one being El Quiñón, Seseña Nueva, a pharaonic construction instigated by the corrupt constructor and politician Paco "El Pocero", and a symbol of abandonment and excess. El Quiñón became one important subject of many press reports and non-fiction films like Houses for All and €uroestafa. Today, this housing estate has changed its physiognomy: all existing homes have been sold, a total of 5,096, thus turning it into a symbol of recovery. In other words, the case and iconography of Seseña have been used, by the authorities of power, as a mirror of the alleged economic recovery.

Despite Seseña, Schultz-Dornburg's book is still relevant. Hundreds of ghost building projects of different sizes continue to rot across the country, without anybody knowing what to do with them. Although they were supposed to become homes, their iconographic meaning has become one of a garbage dump-ruin. In fact, many of these half-constructions have literally become improvised landfills, after they had been looted. This is the case, to name just one, with Soto del Real (Buniel, Burgos), which today should be housing 1,600 families (BRUNAT, 2017). Time has simply stopped there, meaningless. Just to underline the absurdity, Jordi Punti has proposed transforming similar places into theatre stages:

"A good way to make sense of all this nonsense would be via a tribute to the absurd, courtesy of Samuel Beckett. It might seem irreverent to you, but it would involve setting up a traveling theater company which would go through Spain in search of those open spaces. Once they had arrived, nothing would seem more logical than for them to perform Waiting for Godot. The stage would be natural: a lamppost next to a vacant lot; a halfasphalted highway and a traffic sign; a palm tree next to a broken advertisement for a real estate project; the inside of an empty pool, with puddles in it. Then at dusk, in the half-light, Estragon would appear and he would say to Vladimir: "Nothing to be done"' (PUNTÍ, 2012: 117-119).

This Spanish landscape is linked to the global geography of architectonic waste: for example, those that exist in many different Chinese cities, built and then abandoned, and where you can also explore a megalomaniac topography of real estate lucre. If in the previous section we talked about war ruins, in this one we are focusing our gaze on ruins seen as broken-down materials, a devastated landscape that is the product of pure economic 
speculation, which evokes the idea of a real estate corpse, as included on the database cadaveresinmobiliarios. org, which is promoted by researchers like Pablo Arboleda, groups like Basurama and ecologist organizations like Ecologistas en Acción, all pursuing different purposes:

"Firstly, to identify spaces and land areas which may (because of their values, property or situation) have their status reversed to that of rustic or protected land, and to reclaim them. Also, to identify those more urban spaces (buildings, plots) which, due to their location, ownership or characteristics, can be adapted for other uses such as social facilities, urban allotments or even social housing, using what has already been built instead of continuing to expand. Or in other cases, to call for the demolition and/or restoration of the land (there are too many large failed developments). In short, what drives us on is a practical, activist aim, which is not necessarily incompatible with rigor or any other more analytical or artistic approaches" (ARBOLEDA, RUINAS MODERNAS et al., n.d.).

Finally, the landscapes of ruins that are scattered around the world today constitute a sign of identity of the prevailing neoliberalism. Their aesthetic singularity is that they do not express nostalgia for a past time, let alone the sublime nature of ancient ruins, but the validity of an aberrant phase of capitalism in which speculation has outstripped any kind of rational planning. In Korcheck's words:

"If market speculation is always future-oriented, driven by an ever accelerating and unchecked flow of capital and investment, then the photographs break the illusion of speculation as progress and development, slowing or pausing the viewer's gaze upon the fresh remains of the speculative economy" (KORCHECK, 2015: 92).

Wounds, scars and "memetic" razor cuts

“This freeway goes nowhere! Don't worry, it will create places."

El Roto 6

The mass construction of homes has gone hand-in-hand with the construction of infrastructures, driven by state investment, EU funding, loans from the European Investment Bank and strong private investment:

"the new residential typologies (the terraced house boom) in the urban and metropolitan suburbs have had a decisive impact on the marked spatial occupation of the new territorial developments. Thus, the creation of transport infrastructure (highways, highspeed trains, airports, large ports, etc.) has been truly spectacular" (FERNÁNDEZ DURÁN, 2006: 13).

Ramón Fernández Durán has described the urban-agro-industrial complex, the human interventions on the planet as a whole, as a "second skin" (FERNÁNDEZ DURÁN, 2010) different to the biosphere (first skin) and the image society (third skin). Significantly, from an iconographic point of view, we can find a series of works that refer to the urban planning excesses on the land as razor cuts, scars and wounds; that is, as aggressions against the planet's skin.

In 1977, Autopista, unha navallada á nosa terra (Llorenç Soler, 1977) was screened in many Galician towns and cities, on commission by the coordinator of the fight against the Autopista del Atlántico (Atlantic freeway). It was a pioneering film on 
the issue, an instrument designed to raise awareness about the construction of a freeway that divided Galicia in two, causing many demolitions, expropriations, and expulsions of original populations, all expressed with the tough narrative style that Soler used in those years: testimonies from the affected people (in audios that were roughly recorded, almost inaudible) alternating and overlapping with images that show the magnitude of the construction, its open veins.

In general, counter to the story of progress that surrounds the construction of roads, there is a figurative iconography that operates as a "testimony of the pain of landscapes and territories" (LEPASTIER, 2015: 355). Today, in the Spanish context, multiple forms of audiovisual militancy on the transformation of landscape and its consequences proliferate. Nación Rotonda ("Roundabout Nation") documents the inventory of changing use of the land in the last fifteen years, through a collaborative project that invites people to identify on a map the urban planning atrocities existing in many towns and cities on the peninsula and the islands. This critical participatory cartography has thousands of entries that make up the most complete existing archive of land aggressions, mainly focusing on the abandoned roads and freeways, and particularly emphasizing roundabouts.

The members of Nación Rotonda define the practice itself as follows: "It is a way of popularizing a very technical thing that is urbanism" (CARRETERO, 2015). To carry out this popularization, they mainly use aerial imagery comparing the present and past of the area - to highlight the trail of hyperexploitation. These images are attached to photographs of the locations taken on the same ground, thus offering another view of the "corpse" in question so that people can see it clearly.
The possibilities of collaboration that were opened up by the 2.0 context have facilitated the subversive reinvention of the survey or photographic mission: a form of toponymic representation, initiated at the end of the 19th century, which was commissioned by governments to document monuments and public construction works. For example, the French Mission Héliographique sent in 1851 five photographers to take shots of historical national monuments, thereby making patriotic use of photography almost from the very start. In contrast, the survey that Nación Rotonda proposes isn't a public commission at all. Using Google images, individual contributions and trips by group members, it documents a wide catalog of monuments to excess and abandonment. The ironic Nación Rotonda slogan adopts an expression that is commonly used in conversations about the transformation of the land: "Antes aquí todo era campo" ("This all used to be countryside"). Among the milestones achieved, we should mention the publication of the homonymous book Nación Rotonda (TRAPIELLO, ALVÁREZ, GARCÍA and TRAPIELLO, 2015), thanks to a crowdfunding campaign. 8,000 $€$ was needed; 972 sponsors contributed $28,151 €$.

The circulation of the visual motif that interests me in the media sphere has taken place for several years on social media. We could call this kind of militant intervention memeology of ruins, because its aim is for the iconography in question (together with the associated environmental and landscape consequences) to go viral'. Besides the experiences mentioned so far, other groups such as Terra Ferida ("Wounded Land") have also developed a visual critique approach that is similar to that of Nación Rotonda. The organization's logo shows Mallorca completely devastated by highways 
and roads. The visual metaphor is no exaggeration, since nowadays "the surface area required to satisfy the ecological land deficit is about 14.7 or 17.7 times the available land surface in the Balearic Islands" (MURRAY, 2012: 2894). That is, the level of current mobility in the islands would require an area 15 times bigger, 15 archipelagoes.

Terra Ferida participates in and promotes protest campaigns - along with the Balearic Ornithology Group (with the acronym GOB) and the monographic Tot inclòs ("Everything Included", published by the Libertarian Coordinator of Mallorca) - against the Balearic development model, which is based on construction and tourism. It is an organization which, apart from shining a light on the ruins, has become a political actor that tackles non-compliance of political programs and administrations. Not only does it document and organize artistic critiques, it also embarks upon legal battles and stages mobilizations oriented towards social justice and the conservation of the environment on the islands. Thus, Terra Ferida's protests display the destroyed landscape as a way of popularizing, and trying to reverse, the ecological footprint of one of the world's main touristic powerhouses.

\section{Conclusions}

The fragment from the novel On the Edge has helped to catalyze a comparative exercise in cinema, television, and photography on the visual motif of the ruins of the real estate crisis in nonfiction images. The landscape after the battle makes for a rather evocative image that suggests multiple ruined figures - poor, indebted, exiled or displaced - which point to the parallels between war and crisis. Meanwhile, the movements of those defeated by the crisis (such as the $\mathrm{PAH}$ ) and the audiovisual and collaborative militancy of different groups exemplify different ways of dealing critically with a situation that is causing enormous discontent among the population.

Furthermore, these ruins have also been a focus of attention for initiatives related to the environmental movement, which has implemented visual critiques through the circulation of memes. The parallelism between Ballard's imagery and nonfiction post-crisis representations makes it possible to produce a critique of the ideology of progress, by focusing on environmental issues. In this sense, the ruins also become allegories: the landscape is covered with razor cuts, wounds, scars and metastases which, at the visual level, resemble an illness: the usefulness of so much construction is strongly challenged.

For all these reasons, it is useful to refer everything to the critique of capitalism contributed by Walter Benjamin in various texts. This functions as a footnote to the images of the ruins of the real estate crisis: the view of defeated people and environmental destruction highlights the need for a drastic change of model, in which sustainability and the guarantee to the right to housing must not be conspicuous by their absence. In this sense, the visual motif of the ruins becomes a reminder of inequality and environmental abuse.

The iconography of these ruins has generated two main types of images: firstly, the landscape phantasmagoria, the urban emptiness of images on the ground, which are the ones that are dealt with in the first section, and secondly the aerial images, the open wounds, and scars, which are tackled in the second section of the article.

At an iconographic level, the ruins of the Spanish crisis are a crucial part of the landscape of neoliberalism. Synonymous with garbage, real 
estate speculation and disease of the second skin, this landscape cannot be compared with the sublime nature of ancient ruins. Rather, they are everyday ruins of a present in which the value of change is far above the value of use, with all the negative consequences that this entails. They are ruins that show a rather grave clinical profile.

The skeletons of empty homes and the residual stump of roads evoke, through their nonfiction status, the Ballardian universe of catastrophic science fiction, applied to the immediate, local present:

"The most accurate images of the story describe degraded roads, [...] closed supermarkets and crowns of hotels on successive, equally abandoned seafronts. [...] Like the pages of Low-Flying Aircraft (J.G.
Ballard, 1974), the work of SchultzDornburg confronts our gaze with the ruins of an urban modernity as magnificent and totalizing as it is disfigured in its own abandonment" (MUÑOZ, 2012: 7-9).

Finally, the ruins also speak of the violation of Article 47 of the Spanish Constitution. Because of this, it is no exaggeration to claim that, just like in wartime, when a state of emergency is declared, part of the charter of rights is revoked, although it is not an armed conflict that has rescinded democratic guarantees such as housing, but another form of exceptionality deriving from the mandates of the markets.

Translated by Daniela Torres Montenegro (See original texts at the end of the journal)

1/ In accordance with the definition in the Collins Dictionary, by Ballardian I mean: "resembling or suggestive of the conditions described in Ballard's novels and stories, esp dystopian modernity, bleak man-made landscapes, and the psychological effects of technological, social or environmental developments".

2/ The Management Company for Assets Deriving from Bank Restructuring (SAREB) is a public limited company, owned $55 \%$ by public capital and $45 \%$ by private equity, responsible for the management of the real estate assets of four banking entities that went bankrupt.

3/ "All Spaniards are entitled to enjoy decent and adequate housing. The public authorities shall promote the necessary conditions and shall establish appropriate standards in order to make this right effective, regulating land use in accordance with the general interest in order to prevent speculation".

4/ The imaginary Valencian town in which most of Chirbes' novels are set.

5/ The news story, published on 06/18/2005, is quoted in FERNÁNDEZ DURÁN, 2006: 1. Also available at https://www.economist.com/leaders/2005/06/16/after-the-fall [accessed: January 28th 2019]

6/ Cartoon published in El País, 09/09/2011.

7/ As of today, the Twitter account has more than 19,000 followers which, together with more than 10,000 Facebook friends, make social networks the main means of communication and dissemination of the ruins resulting from the crisis. 
ARBOLEDA, Pablo; RUINAS MODERNAS et al. (n.d.). "Objetivos de cada colectivo o individuo". Cadáveres inmobiliarios. Retrieved from: http:// cadaveresinmobiliarios.org/objetivos-de-cada-colectivo-o-individuo/ [access: November 9th 2018].

ARGULLOL, Rafael (2012). El gran saqueo. SCHULTZ-DORNBURG, Julia, Ruinas modernas. Una topografia del lucro (p. 71-74). Barcelona: Àmbit.

AUKEN, Margarete (2009). Auken Report. Approved by the European Parliament on March 26th 2009.

Ballardian (s.d.). Collins English Dictionary. Retrieved from: https://www. collinsdictionary.com/dictionary/english/ballardian [access: February 3rd 2019]

BALLÓ, Jordi and BERGALA, Alain (eds.) (2016). Motivos visuales del cine. Barcelona: Galaxia Gutenberg.

BASURAMA (2011). 6000 km. Paisajes después de la batalla. Navarra. Available at: www. $6000 \mathrm{~km} .0 \mathrm{rg}$

BENJAMIN, Walter (2013). Libro de los pasajes. Madrid: Akal.

BRUNAT, David (2017). Las promociones fantasma se pudren en silencio: "Nunca nadie querrá vivir aquí". El Confidencial, February 20th 2017. Retrieved from: http://www.elconfidencial.com/vivienda/2017-02-20/promocionesurbanizaciones-fantasma-se-pudren_1331763/ [access: April 5th 2017].

CALVO ROY, José Manuel (1997). "Yo soy el milagro”, asegura Aznar al diario estadounidense 'Wall Street Journal'. El País, May 21st 1997. Retrieved from: https://elpais.com/diario/1997/05/21/economia/864165602_850215.html [access: April 5th 2018].

CARRETERO, Rodrigo (2015). Nación rotonda: 10 ejemplos de desastres urbanísticos de la crisis (FOTOS ANTES Y DESPUÉS). Huffington Post, August 5th 2015. Retrieved from: http://www.huffingtonpost.es/2015/06/24/nacionrotonda_n_7654460.html [access: May 4th 2018].

CHIRBES, Rafael (2016). On the Edge. New York: New Directions Publishing.

COSTA, Jordi (dir.) (2008). J.G. Ballard. Autòpsia del nou mil·leni. Barcelona: CCCB/Diputació de Barcelona.

DÍEZ, Anabel (2003). Zapatero culpa al Gobierno de desoír sus avisos sobre el posible estallido de la vivienda. El País, October 4th 2003. Retrieved from: https://elpais.com/diario/2003/10/04/espana/1065218417_850215.html [access: April 5th 2018].

EL PAIIS (2007). Zapatero garantiza que España está a salvo de la crisis financiera. El País, August 22nd 2007. Retrieved from: https://elpais.com/ diario/2007/08/22/portada/1187733606_850215.html [access: April 5th 2018].

FERNÁNDEZ DURÁN, Ramón (2006). El Tsunami urbanizador español y mundial. Ecologistas en acción. Retrieved from: www.ecologistasenaccion. org/article.php3?id_article=4824 [access: April 5th 2018].

FERNÁNDEZ DURÁN, Ramón (2010). Tercera piel. Sociedad de la imagen y conquista del alma. Barcelona: Virus editorial.

GARRIDO, Alejandro (2011). Cabanyal 2011 - Consumo de lugar. Left Hand Rotation - El museo de los desplazados. Retrieved from:

http://www.lefthandrotation.com/museodesplazados/ficha_a_garrido. html [access: April 5th 2018]. 
HISPANO, Andrés (2005). Soñando nuestra ruina. MARÍ, Antoni (ed.), El esplendor de la ruina (p. 173-183). Barcelona: Fundació Caixa Catalunya.

KORCHECK, Kathy (2015). Speculative Ruins: Photographic Interrogations of the Spanish Economic Crisis. Arizona Journal of Hispanic Cultural Studies, Vol. 19, p. 91-108.

LEAL, José F. (2009). Los diez azotes de Auken al ladrillo español. El Mundo, March 26th 2009. Retrieved from: www.elmundo.es/elmundo/2009/03/26/ suvivienda/1238071948.html [access: April 5th 2018].

LEPASTIER, Joachim (2016). La cicatriz. BALLÓ, Jordi and BERGALA, Alain (eds.), Motivos visuales del cine (p. 353-355). Barcelona: Galaxia Gutenberg.

LÖWY, Michael (2005). Fire Alarm: Reading Walter Benjamin's 'On the Concept of History'. London: Verso.

MARÍ, Antoni (2005). El esplendor de la ruina. MARÍ, Antoni (ed.), El esplendor de la ruina (p. 13-21). Barcelona: Fundació Caixa Catalunya.

MARÍ, Antoni (2016). La ruina. BALLÓ, Jordi and BERGALA, Alain (eds.), Motivos visuales del cine (p. 214-219). Barcelona: Galaxia Gutenberg.

MUÑOZ, Francesc (2012). Prólogo. SCHULTZ-DORNBURG, Julia, Ruinas modernas. Una topografia del lucro (p. 7-10). Barcelona: Àmbit.

MURRAY, Ivan (2012). Geografies del capitalisme balear: poder, metabolisme socioeconòmic i petjada ecològica d'una superpotència turística, vol. 3. Palma de Mallorca: Universitat de les Illes Balears, Departament de Ciències de la Terra. Retrieved from: http://hdl.handle.net/10803/104203 [access: November 9th 2018].

PUNTí, Jordi (2012). Arqueología del futuro. SCHULTZ-DORNBURG, Julia, Ruinas modernas. Una topografia del lucro (p. 117-119). Barcelona: Àmbit.

REDACCIÓN IDEALISTA (2017). El lastre de la vivienda: aún arrastra 1,36 millones de casas vacías en venta por toda España. Idealista, September 15th 2017. Retrieved from: http://www.idealista.com/news/inmobiliario/ vivienda/2017/09/14/747998-el-lastre-de-la-vivienda-aun-arrastra-1-36millones-de-casas-vacias-en-venta-por [access: April 5th 2018].

REYES MATE, Manuel (2006). Medianoche en la historia: Comentarios a las tesis de Walter Benjamin «Sobre el concepto de historia». Madrid:Trotta.

SALIDO COBO, Jorge (2016). La recuperación Inmobiliaria llega a la ciudad de "El Pocero" en Seseña. El Mundo, April 22nd 2016. Retrieved from: http:// www.elmundo.es/economia/2016/04/22/57190cbe468aeb39418b45ee.html [access: April 5th 2018].

SCHULTZ-DORNBURG, Julia (2012). Ruinas modernas. Una topografia del lucro. Barcelona: Àmbit.

TRAPIELLO, Guillermo; ÁLVAREZ, Miguel; GARCÍA, Esteban and TRAPIELLO, Rafael. (2015). Nación Rotonda. Madrid: PHREE.

How to quote GUAL, Joan Miquel (2019). Ruins. A visual motif of the Spanish real estate crisis. Comparative Cinema, Vol. VII, No. 12, p. 5368. DOI: 10.31009/cc.2019.v7.112.04 

Joan Miquel
Vol. VII comparative cinema

Gual

\section{Ruïnes. Motiu visual de la crisi immobiliària espanyola}

Les ruïnes han exemplificat històricament els imperis caiguts, també el paisatge posterior a la batalla. Progressivament, amb la urbanització del món, cada cop hi ha més ruïnes que són fruit d'una construcció a gran velocitat que va deixant rastres visibles: mirades des de perspectives aèries, s'assemblen a metàstasis o cicatrius. Aquestes ruïnes esdevenen escombraries, desfets d'una explotació intensiva del territori gestada a partir de la lògica d'acumulació de capital, no en funció dels interessos de les persones o la sostenibilitat mediambiental. Molts treballs televisius, cinematogràfics o fotogràfics han abordat el motiu visual de les ruïnes en el marc de la crisi immobiliària iniciada el 2008. Aquest escrit vol contribuir a la reflexió sobre la qüestió, prenent en consideració diferents obres de no ficció posteriors a la publicació de l'Informe Auken (2009). L'objectiu perseguit és el d'evidenciar l'abundància de representacions audiovisuals que, més enllà del testimoni, han apuntat crítiques al model de desenvolupament espanyol des de la perspectiva mediambiental i de la forta desigualtat que ha generat.

Paraules Clau

RUIINES

MOTIU VISUAL

CRISI IMMOBILIÀRIA

DESTRUCCIÓ MEDIAMBIENTAL

MILITÀNCIA

CINEMA

FOTOGRAFIA

ESPANYA

Data de recepció: 09/04/2018

Data d'acceptació: 28/08/2018

Joan Miquel Gual Professor col-laborador a la Universitat Oberta de Catalunya. Imparteix Història del Cinema i Arts en Pantalla. Doctor en Teoria, Anàlisi i Documentació Cinematogràfica per la Universitat Pompeu Fabra i Màster en Teoria i Pràctica del Documental Creatiu a la Universitat Autònoma de Barcelona. També és activista d'habitatge. Ha participat a moviments socials com VdeVivienda i forma part de la cooperativa d'habitatge La Borda SCCL, que s'acaba de construir a Can Batlló. Actualment, investiga la imatge de la bombolla immobiliària espanyola en el cinema, la fotografia i la literatura. Està preparant un llibre sobre la qüestió. 


\section{Ruïnes i paisatge. Un debat viu}

"La radio habla cada mañana del estallido de la burbuja inmobiliaria, la desbocada deuda pública, la prima de riesgo, la quiebra de las cajas de ahorros y la necesidad de establecer recortes sociales y llevar a cabo la reforma laboral. Es la crisis. Las cifras en España superan el veinte por ciento de paro y el año que viene pueden subir hasta el veintitrés o veinticuatro. Muchos de

los emigrantes viven del subsidio de empleo [...] Hace cinco o seis años todo el mundo trabajaba, la comarca entera en obras. Parecía que no iba a quedarse ni un centímetro de terreno sin hormigonar; en la actualidad, el paisaje tiene algo de campo de batalla abandonado,

o de territorio sujeto a un armisticio: tierras cubiertas de hierba; naranjales convertidos en solares; frutales descuidados, muchos de ellos secos; tapias que encierran pedazos de nada.»

(Rafael Chirbes, En la orilla)

El tema d'aquesta recerca és la representació de les ruïnes emergides en el paisatge espanyol després de la crisi immobiliària iniciada l'any 2008. Les ruïnes en qüestió existeixen a causa d'un excés de construcció a Espanya, a on s'edificaren, en el màxim apogeu, més habitatges que al conjunt format per Alemanya, Itàlia i França. Específicament, l'any 2005, s'iniciaren més de 800.000 habitatges sense que hi hagués demanda per comprar-los.

Més enllà d'aquesta construcció excessiva, la crisi tingué lloc a causa d'un entrellaçat de polítiques públiques i interessos del sistema financer que fomentaren la compra massiva d'habitatges mitjançant hipoteques. Quan el cicle constructor es detingué, moltes famílies quedaren a l'atur i no van poder retornar els préstecs bancaris contractats. D'aquesta manera, els principals bancs i caixes d'estalvi van fer fallida i l'estat espanyol acudí al seu rescat, seguint els dictats de recuperació imposats per la Troika (Comissió Europea, Banc Central Europeu i Fons Monetari Internacional).

El fragment introductori de la novel-la En la orilla està escrit en un dels anys més durs de la crisi espanyola (2013), i condensa bona part de la iconografia a què l'article pararà atenció. La idea de presentar el paisatge urbà de manera metafòrica, com les restes posteriors a una batalla, es vincularà, en el primer epígraf -Ruïnes d'una guerra sense morts-, al paisatge humà que ha generat el moment històric: els arruïnats per la crisi o derrotats a la guerra sense morts immobiliària.

Per aproximar-nos al sentit d'aquesta iconografia de no ficció i relativa al present històric, resulta pertinent la següent afirmació:

«El espectáculo de la ruina, desde la Primera Guerra Mundial, no muestra ninguna memoria del pasado, ni remite a la historia, ni a ninguna contemplación sobre lo que se ha perdido. La ruina, a partir de este momento, es una ruina del presente, de un presente inmediato que tenemos frente a nosotros, y no remite a otra cosa que a ella misma [...] De ahí procede el realismo con el que se representará la ruina, y no habrá ningún medio de expresión más eficaz o elocuente que el de la fotografía, el cine y el documental para mostrar el realismo que esta realidad arruinada exige» (MARÍ, 2005: 20).

Per vincular la idea que exposa Marí al context espanyol contemporani, resulta apropiat tenir en compte el concepte de ruïnes especulatives (speculative ruins), elaborat per Kathy Korcheck en relació a la representació fotogràfica de la crisi espanyola portada a terme en els treballs de Markel Redondo, Julia Schulz-Dornburg i Cadeslasver- 
des: "Les "ruïnes especulatives" apunten cap a la noció d" "especulació" del mercat i fan referència a la conceptualització d' "espectacle" de Guy Debord, "la imatge perfecta de l'ordre econòmic dominant", on "els fins no són res i el desenvolupament ho és tot"» (2015: 92). Les ruïnes de la crisi, sempre en la visió de Korcheck, produeixen una visió anti-nostàlgica en qui les mira, que serveix per articular una crítica al capitalisme i la societat de l'espectacle que el legitima.

Per altra banda, les ruïnes en qüestió també seran definides com a ruïnes ballardianes ${ }^{1}$, és a dir, com a residus arquitectònics provinents de l'hybris constructora. Dit això, en cap cas es tracta d'evocar, com a la ciència-ficció, un hipotètic futur distòpic que està per arribar, en la línia de les ruïnes somniades pel cinema que ha recollit Andrés Hispano (2005: 173-183), sinó d'assenyalar un present inquietant:

"La ruina nos hace reflexionar sobre la fragilidad del mundo contemporáneo. Una fragilidad cotidiana, recurrente a lo largo de la historia, pero que ahora ha adquirido una dimensión que no se había considerado anteriormente. Una fragilidad cultural, energética, económica, demográfica y biológica» (MARí, 2005: 21).

Un referent acadèmic d'iconografia fílmica que es prendrà en consideració serà Motivos visuales del cine (BALLÓ i BERGALA, 2016), una taxonòmica reflexió a moltes veus que parteix d'una declaració ben clara: «Ojalá que este libro, escrito "a dos países", como decimos de una pieza musical que se toca a "cuatro manos", pueda suscitar el surgimiento de un auténtica teoría del motivo en el cine» (2016: 16). Si bé no existeix una teoria del motiu visual en el cinema, el text La cicatriz (LEPASTIER, 2016: 353-355) resulta de gran utilitat per a aquest article, principalment en el segon epígraf: Ruïnes dis- tòpiques. Els cadàvers immobiliaris com a crítica i militància.

A banda del cinema, la circulació de la iconografia de no ficció que ens interessa ha estat impulsada fortament per iniciatives vinculades al moviment ecologista, fent ús de les xarxes socials. Els col-lectius Terra Ferida, Nación Rotonda i Basurama han dedicat molts esforços a fotografiar la fesomia de l'esclat de la bombolla: cadàvers immobiliaris arreu de la geografia de l'estat; metafòriques carreteres inacabades que no arriben enlloc; epidermis territorials vistes des de l'aire que s'assemblen a tumors, a metàstasis avançades, a talls de navalla. Tot plegat ha consolidat una memètica crítica que ha donat peu a una nova forma d'intervenció militant i denúncia, que pren en consideració les ruïnes com a objecte principal.

En contraposició, el poder econòmic i polític ha fet una lectura antagònica del mateix context. Des de la perspectiva dels diferents governs que han hagut de gestionar la crisi immobiliària, les ruïnes simplement exemplifiquen un moment estacionari, que pot ser superat mitjançant polítiques públiques adequades, orientades a vendre al millor preu els estocs d'habitatge i infraestructures disponibles, en el menor marge de temps. Aquesta és la funció de la SAREB o banc dolent ${ }^{2}$. En aquest marc ideològic, el cas de Seseña resultaria paradigmàtic: d'icona de la crisi i l'excés, a territori on viuen avui moltes famílies. De ruïnes a símbol de recuperació.

Aquesta interpretació de la crisi, i de les ruïnes que se'n deriven, com una transició i un efecte totalment superables, es posarà en diàleg amb altres perspectives, com l'Informe Auken: aprovat pel Parlament Europeu el 2009, qüestionà el model de desenvolupament espanyol i proposà una sèrie de mesures per revertir la situació, sense 
que cap política de reorientació substantiva a favor del dret a l'habitatge i la preservació del medi ambient hagi estat aplicada a dia d'avui.

Finalment, el motiu visual esmentat serà emmarcat en les idees benjaminianes de les ruïnes de la Història. Per a l'alemany, les ruïnes resulten sinònim d'una catàstrofe humana provinent del passat, contrària a l'evolució envers el futur. Les ruïnes sintetitzen visualment la crítica del progrés formulada per Benjamin en la novena tesi "sobre el concepte d'Història". Aquesta és presentada amb l'al-legoria d'una tempesta que bufa des del paradís, empenyent l'àngel de la Història contra la seva voluntat, mentre contempla impotent el desastre de les ruïnes que s'amunteguen davant seu. El vent: «[...] lo empuja irresistiblemente hacia el futuro, al cual da la espalda, mientras que frente a él las ruinas se acumulan hasta el cielo. Esa tempestad es lo que llamamos progreso" (BENJAMIN a LÖWY, 2003: 101). A la crisi espanyola, l'àngel de la Història sobrevola paratges "ballardians".

\section{Ruïnes d'una guerra sense morts}

Els edificis buits són la principal figura de la ruïna immobiliària, però no és una figura immutable. Trobem casos en què aquests edificis es reutilitzen per viure, i d'altres en què la ruïna es troba en la figuració humana dels desplaçats a l'estranger o de les víctimes de la gentrificació.

El projecte del col-lectiu Basurama $6000 \mathrm{~km}$ convida a «reflexionar sobre el metabolismo de las ciudades, haciendo visibles ciertos paisajes-territorios relacionados con la producción, consumo y deshecho de materiales y energía» (BASURAMA, 2011). 6000 kilòmetres és el recorregut per les ruïnes immobiliàries ubicades a tota la geografia peninsular, així com també els kilòmetres d'autopista que el PEIT (Pla Estratègic d'Infraestructures de Transport) preveu construir a l'estat espanyol abans de 2020. El subtítol del projecte connecta amb el fragment de Chirbes reproduït més amunt: «Paisaje después de la batalla».

$6000 \mathrm{~km}$ articula diferents projectes expositius, un mapa col-laboratiu i un llibre digital. Aquest últim ensenya un total de trenta-una ubicacions. Cada una d'elles és presentada en una fitxa que consta d'una fotografia, una breu descripció de l'obra urbanística i el seu estat d'abandonament, la situació geogràfica de la mateixa, les dimensions a escala i una cita expressiva d'un text de diferents fonts, segons el cas - novel-la, escrits de geografia urbana, diàlegs de pel-lícules, etc.- . En conjunt, es tracta d'un treball que pot ser qualificat de benjaminià, atesos la forma i l'objectiu polític que persegueix. En el pla formal, presenta una estètica de la cita i la referència, assimilable als capítols del Libro de los Pasajes (BENJAMIN, 2013). La suma de fragments i imatges busca produir un efecte polític determinat: articular una crítica visual que evidenciï el fracàs del model de desenvolupament espanyol.

La devastació del territori espanyol a què fa referència $6000 \mathrm{~km}$ ha suposat una transformació tan profunda del paisatge que permet adaptar al present aquella famosa cita d'Estrabó, l'historiador i geògraf grec que afirmà que, durant l'època romana, un esquirol podia travessar de nord a sud la península sense baixar dels arbres. Avui dia, l'esquirol podria creuar de nord a sud sense tocar el terra, saltant de ruïna en ruïna.

Com a exemple expressiu de $6000 \mathrm{~km}$, només cal mirar la fitxa numero vuit: "Urbanización abandonada en Llanos de Velerín» (Estepona, Málaga), formada per trenta-cinc habitatges repartits en una extensió de 2'4 hec- 
tàrees. Aquest indret també apareix en el llargmetratge de no ficció Casas para todos (Gereon Wetzel, 2013), que mostra com, sorprenentment, els immobles buits han estat reutilitzats per part de l'exèrcit espanyol. L'escenari, que el col-lectiu artístic presenta com un paisatge posterior a la batalla, Wetzel el mostra reconvertit en un camp d'entrenament on soldats assagen tècniques de defensa i emboscada. D'aquesta manera, la metàfora del paisatge de guerra s'apropa a la plena literalitat.

Mercado de futuros (Mercedes Álvarez, 2011) permet aprofundir en la iconografia plantejada fins aquí. Aquest llargmetratge de no ficció intercala escenes de l'enderrocament d'un pis antic $a m b$ seqüències com aquella en què sentim un gran guru del show business citant Rothschild en una conferència acadèmica: "Les grans fortunes s'acumulen mentre les bombes cauen sobre el port, no quan els violins sonen als salons". D'aquesta manera, el film reflecteix la idea de la crisi entesa, des de la perspectiva del poder econòmic, com una oportunitat de negoci, un camp d'emprenedoria en què aplicar la destrucció creativa schumpeteriana, i una possibilitat especulativa plena d'ofertes, en un context, el del present del film, en què a Espanya els preus de l'habitatge havien descendit considerablement.

Si bé Mercado de futuros deixa clar qui són els guanyadors de la batalla, les ruïnes evidencien que hi ha hagut molts més derrotats. Sense anar més lluny, cal esmentar el moviment ecologista, al qual dedicarem una reflexió aprofundida en el següent epígraf. Aquí parlarem, en primer lloc, de la iconografia de la reutilització dels habitatges buits, de la conversió dels esquelets immobiliaris en màquines de viure, a mans de persones i famílies desnonades de la seva llar.

L'any 2017, el portal Idealista pu- blicava el següent titular: «El lastre de la vivienda: aún arrastra 1'36 millones de viviendas vacías en venta por toda España» (REDACCIÓN IDEALISTA, 2017). La notícia explica que s'havien absorbit 348.000 habitatges des de 2010 , any en què el pic de cases buides se situà en el punt més alt. La notícia també exposa que entre 2012 i 2015 es produïren 177.900 desnonaments (dades del Banc d'Espanya), els quals, sumats als 244.000 que tingueren lloc, segons la Plataforma d'Afectats per la Hipoteca (PAH), entre 2008 i 2011, deixen un total de més de 400.000 famílies que han perdut la llar entre 2008 i 2015.

En aquest marc, documentals com La Plataforma (Jon Herranz, 2012) o Sí se puede. Siete días en la PAH de Barcelona (Pau Faus, 2014) ensenyen el procés d'autoorganització d'un dels moviments socials de major incidència a l'Espanya democràtica. Un dels eslògans més coneguts de la PAH és «No s'entén, gent sense cases i cases sense gent!». Centenars d'edificis ocupats amb el domàs indicatiu "Obra Social de la $\mathrm{PAH}$ », els manuals que ensenyen com ocupar a la gent comuna, o els mapes interactius d'habitatges buits generats des de la Plataforma, formen part d'aquesta iconografia de la recuperació popular de les ruïnes per fer efectiu el dret a l'habitatge, contemplat a l'article 47 de la Constitución ${ }^{3}$. Tal iconografia també està present en el film de Wetzel esmentat més amunt, el qual mostra l'experiència de Corrala Utopía, un edifici ocupat per famílies andaluses sense recursos.

En segon lloc, l'empobriment derivat de la crisi va acaparar molta atenció televisiva i mediàtica en els anys de major intensitat, tant a nivell nacional com internacional. Del gran nombre de reportatges sobre la qüestió que es podrien mencionar, destacarem The Great Spanish Crash (BBC, 2012). Aquest es fixà específicament en la Comunitat Valenciana per explicar com va tenir 
lloc el crack econòmic general. Un dels indrets escollits per mostrar els efectes de la crisi és el poblet alacantí de Sant Miquel de Salines, similar al Misent de Chirbes 4 : un poble costaner valencià imaginari amb abundants obres abandonades, allà on abans hi havia boscos de grues funcionant a ple rendiment.

Com a conseqüència de la paràlisi constructora, el reportatge ensenya el programa d'una associació de veïns orientat a facilitar l'ocupació dels aturats de llarga durada. La mateixa associació també posa a disposició de la gent més necessitada un banc d'aliments, on es poden obtenir béns de primera necessitat: llet i sucre, per exemple. Per completar el panorama d'empobriment, el reporter entrevista joves sense feina, exiliats laborals a d'altres països. En aquest cas, les ruïnes resulten sinònim d'exili econòmic, d'emigració forçada a la recerca d'un destí millor a l'estranger per manca d'oportunitats, un tema abordat també a documentals com Españoles en el exilio (Rubén Hornillo, 2015) o En tierra extraña (Icíar Bollaín, 2014).

En tercer lloc, s'ha d'esmentar una altra iconografia vinculada al cicle immobiliari: les ruïnes de la gentrificació, un procés indestriable de la figura humana del desplaçat, dels expulsats per la reforma urbana i el model de ciutat. En construcción (José Luís Guerín, 2001) ja va suposar un exemple pre-crisi de la substitució social o gentrificació al barceloní barri del Raval, després d'una important transformació urbanística. Posteriorment, hi ha hagut tantes persones forçades a abandonar determinats barris que el col-lectiu madrileny Left Hand Rotation ha plantejat la creació de l'arxiu col-laboratiu El museo de los desplazados. Aquest documenta, a partir d'aportacions individuals, els casos d'expulsió de veïnat que tenen lloc a molts indrets del món, si bé en bona part estan situats a l'estat espanyol.
Com a exemple de la documentació work in progress, aquí mencionarem el treball fotogràfic Consumo de lugar -un dels tres que formen part del projecte d'Alejandro S. Garrido sobre el Cabanyal (València)-. Aquest ensenya moltes ruïnes i apareix descrit de la següent manera pel seu autor:

«Proyecto visual que circunda la destrucción del Cabanyal en Valencia. El proyecto gira en torno a cómo la producción de una ciudad-marca, la nueva Valencia, pasa por la destrucción del tejido social, el patrimonio cultural y la suplantación de toda heterogeneidad identitaria o discursiva preexistente» (GARRIDO, 2011).

Malgrat aquesta visió unidimensional, cal tenir en compte altres relats més dialèctics sobre el mateix context, mirades com la que proposa Abril al Cabanyal (Sergio Tarín, 2013), sobre els 15 primers anys de resistència de la plataforma Salvem El Cabanyal, o la més actual Cabanyal any zero (Frederic Pressmann, 2018), sobre les mobilitzacions, neguits, fites i esperances de l'actual població del barri valencià.

Com a tancament d'aquest epígraf, direm que a les guerres es produeixen suspensions de drets, situacions de pobresa, exili i desplaçaments de població. Aquestes situacions també han tingut lloc a la crisi financera-immobiliària espanyola que, a partir de la iconografia de les seves abundants ruïnes, pot ser definida com una sort de guerra sense morts. El paisatge urbanístic resultant és completament indestriable del paisatge humà. Ambdós, en concatenació, serveixen per eixamplar i aprofundir el símil productiu entre guerra i crisi, així com per assenyalar un mapa d'arruïnats o derrotats per la contesa que deixa clara la forta desigualtat existent. Per aquesta raó, $i$ altres que veurem a continuació, el paisatge de la crisi és, benjaminianament, un "document de cultura" que també ho és de "barbàrie". 


\section{Ruïnes distòpiques. Els cadàvers immobiliaris com a crítica i militància}

\section{L'Informe Auken en imatges}

L'any 2007, l'aleshores president del govern espanyol José Luís Rodríguez Zapatero afirmà: "España está a salvo de la crisis financiera» (EL PAís, 2007). No obstant, The Economist havia avisat dos anys abans que "Nunca habían crecido tanto los precios de la vivienda, por tanto tiempo y en tantos países [...] El boom inmobiliario global es la mayor burbuja financiera de la historia. Cuanto mayor sea el boom, mayor será el eventual estallido» ${ }^{5}$. Veus com l'ecologista Ramón Fernández Durán (FERNÁNDEZ DURÁN, 2006) o el catedràtic en Economia Immobiliària a la Universitat de Montreal, Ricard Vergés -entrevistat al documental €uroestafa (Guillermo Cruz, 2014) - també avisaren de l'esclat que estava per venir.

L'any 2008 es detingueren les grues a causa de la crisi. En aquells moments, el paisatge espanyol deixà de ser sinònim de "miracle econòmic", tal i com l'havia definit el president José María Aznar (CALVO ROY, 1997), per passar a ser un paisatge de ruïnes $\mathrm{i}$ abandonament. Edificio España (Víctor Moreno, 2012) plasma de manera molt expressiva els efectes de la paràlisi. El títol funciona com una metàfora del país sencer: a través de l'icònic gratacels madrileny, capta la història d'auge i caiguda del cicle immobiliari, sense deixar de banda els desnonaments i la massiva desocupació que l'acompanyaren. Un any abans de l'estrena del documental, «Ningú no ens representa» havia estat un dels eslògans principals del moviment ciutadà $15 \mathrm{M}$. També «iPSOE-PP, la misma mierda es!». Des de les xarxes i les places es va crear el concepte \#PPSOE, per evidenciar que cada cop resultaven més indistingibles els dos partits majoritaris, a causa de les polítiques que aplicaven de manera similar i alineada.
Entre les raons d'aquesta indistinció popular, s'hi trobava la reacció d'ambdues formacions polítiques envers el demolidor Informe Auken. Aquest tractava sobre "El impacto de la urbanización extensiva en España en los derechos individuales de los ciudadanos europeos, el medio ambiente y la aplicación del Derecho comunitario, con fundamento en determinadas peticiones recibidas» (AUKEN, 2009). El text estava redactat a partir de denúncies d'agressions al territori provinents fonamentalment del moviment ecologista. Va ser aprovat aclaparadorament per les i els eurodiputats, si bé amb el vot en contra del Partit Popular i l'abstenció del PSOE. L'informe demanava la congelació de fons comunitaris si no es posava punt i final als abusos urbanístics en el context espanyol. En titulars, els seus punts més crítics eren: 1 . Requalificacions (de terrenys) interessades; 2. Ciutadans/es víctimes econòmiques; 3 . Bona fe vs pocs escrúpols; 4. Les illes, aniquilades per l'especulació; 5. Model espoliador; 6 . Es continuen venent cases il-legals; 7 . Llei de costes quasi ignorada; 8. Demolicions arbitràries; 9. Totes les administracions, culpables; 10. Les sentències no es compleixen (LEAL, 2009).

La traducció en el paisatge de la situació denunciada trobà en el llibre Ruinas modernas (SCHULTZ-DORNBURG, 2012) una interessant i pionera indagació. Topografía del lucro és el seu expressiu subtítol. En total, Schultz mostra en detall 25 promocions frenades, repartides per tota la geografia peninsular i localitzades a través de Google Maps. Acompanya les fotografies, aèries i sobre el terreny, una breu explicació cronològica de la tramitació, planificació, construcció i abandonament dels treballs. Tots els casos tenen en comú un fet: la planificació, excepte en una promoció, va tenir lloc en els anys de creixement sostingut que van de 1993 a 2007. També, en totes les obres menys a una, la data d'abando- 
nament té lloc entre 2008 i 2011 . Ambdues temporalitats coincideixen amb el cicle immobiliari i la crisi respectivament.

Per contra, el capitalisme hispà ha creat els seus propis mites de recuperació. El principal: El Quiñón, Seseña Nueva, una construcció faraònica promoguda pel corrupte constructor i polític Paco "El Pocero", i un símbol d'abandó i d'excés, objecte de nombrosos reportatges de premsa i documentals com Casas para todos i €uroestafa. Avui, aquesta urbanització ha canviat la seva fesomia: s'han venut tots els habitatges existents, un total de 5.096, convertint-se en senya de regeneració. Dit en altres paraules: el cas i la iconografia de Seseña han estat utilitzats, des d'instàncies del poder, com un mirall de la suposada recuperació econòmica.

Malgrat Seseña, el llibre de Schultz-Dornburg continua vigent. Centenars de promocions fantasma de totes les mides es podreixen al llarg i ample del territori, sense que ningú sàpiga què fer amb elles. Si bé havien de ser residències, el seu sentit iconogràfic és el de la ruïna-escombraria. De fet, moltes d'aquestes semi-construccions s'han convertit literalment en improvisats abocadors, després d'haver estat saquejades. És el cas, per citar-ne un, de Soto del Real (Buniel, Burgos), que avui hauria d'allotjar 1.600 famílies (BRUNAT, 2017). Allà el temps s'ha aturat, sense sentit. Per constatar l'absurd, Jordi Puntí proposa convertir els indrets similars en escenari teatral:

«una buena forma de dar sentido a todo ese sinsentido sería a través de un homenaje al absurdo, gentileza de Samuel Beckett. Quizá les parezca irreverente, pero se trataría de montar una compañía de teatro itinerante y que recorriera España en busca de esos espacios abiertos. Una vez allí, nada parecería más lógico que interpre- tar Esperando a Godot. El escenario sería natural: una farola junto a un descampado; una carretera a medio asfaltar y una señal de tráfico; una palmera junto a un anuncio roto de una promoción inmobiliaria; el interior de una piscina vacía, con agua encharcada. Entonces al atardecer, a media luz, aparecería Estragón y le diría a Vladimir: "No hay nada que hacer"» (PUNTÍ, 2012: 117-119).

Aquest paisatge espanyol connecta amb una geografia global dels residus arquitectònics: per exemple, aquells que existeixen a les múltiples ciutats construïdes i abandonades xineses, a on també es pot explorar una megalòmana topografia del lucre immobiliari. Si en l'anterior epígraf parlàvem de ruïnes de guerra, en aquest centrem la mirada en les ruïnes enteses com a material de desfet, com un paisatge devastat fruit de la pura especulació econòmica, el qual evoca la idea de cadàver immobiliari, recollida en la base de dades cadaveresinmobiliarios.org, promoguda per investigadors como $\mathrm{Pa}-$ blo Arboleda, col-lectius com Basurama o organitzacions ecologistes com Ecologistas en Acción, perseguint diferents finalitats:

«En primer lugar, para identificar espacios y suelos que sean susceptibles (por sus valores, propiedad, situación) de revertir su situación a la de suelo rústico o protegido y reivindicarlos. También para identificar aquellos espacios más urbanos (edificios, solares) que por su situación, propiedad o características pueden acoger otros usos como equipamientos sociales, huertos urbanos o incluso viviendas sociales, utilizando lo ya construido en lugar de seguir expandiéndonos. En otros casos para pedir la demolición y/o restauración del terreno (sobran grandes desarrollos fallidos). En 
definitiva, nos mueve un propósito práctico y reivindicativo, lo que no tiene por qué estar reñido con el rigor o con otros enfoques más analíticos o artísticos» (ARBOLEDA, RUINAS MODERNAS et al., n.d.).

Finalment, els paisatges de ruïnes que s'escampen arreu del món resulten, avui dia, una senya identitària del neoliberalisme regnant. La seva singularitat estètica és que no expressen nostàlgia d'un temps passat, ni molt menys el caràcter sublim de les ruïnes antigues, sinó la vigència d'una fase aberrant del capitalisme en què l'especulació supera qualsevol tipus de planificació racional. En paraules de Korcheck:

«Si l'especulació del mercat mira sempre cap al futur, conduïda per un flux de capital i inversió, permanentment accelerat i desenfrenat, les fotografies, en canvi, trenquen la il-lusió de l'especulació com a progrés i desenvolupament, tot ralentint o aturant la mirada de l'espectador sobre els residus frescos de l'economia especulativa»" (KORCHECK, 2015: 92).

\section{Ferides, cicatrius i talls de navalla} "memètics".

“iEsta autopista no lleva a ningún sitio! No te preocupes, los sitios los creará ella.»

\section{El Roto ${ }^{6}$}

La construcció massiva d'habitatges ha anat acompanyada de l'edificació d'infraestructures, impulsades per la inversió estatal, els fons comunitaris, els crèdits del Banc Europeu d'Inversions i una forta inversió privada:

«las nuevas tipologías residenciales (boom del chalet adosado) en las periferias urbanas y metropolitanas han repercutido decisi- vamente en la acusada ocupación espacial de los nuevos desarrollos territoriales. Así, la creación de infraestructura de transporte (autopistas, trenes de alta velocidad, aeropuertos, grandes puertos, etc.) ha sido verdaderamente espectacular» (FERNÁNDEZ DURÁN, 2006: 13).

Ramón Fernández Durán ha definit el complex urbà-agro-industrial, el conjunt d'intervencions humanes en el planeta, con una "segona pell" (FERNÁNDEZ DURÁN, 2010), distinta de la biosfera (primera pell) i la societat de la imatge (tercera pell). Significativament, a nivell iconogràfic, es pot resseguir tota una sèrie de treballs que es refereixen als excessos urbanístics en el territori com a navallades, cicatrius $i$ ferides, és a dir, com a agressions sobre la pell del planeta.

El 1977 es projectava a molts pobles i ciutats gallecs Autopista, unha navallada á nosa terra (Llorenç Soler, 1977), encàrrec de la Coordinadora de la lucha contra la Autopista del Atlántico. Fou un títol pioner sobre la qüestió, un instrument de conscienciació sobre la construcció d'una autopista que dividí Galícia en dues meitats, provocant múltiples enderrocs, expropiacions i expulsions de poblacions originàries, a través de l'estil narratiu dur del Soler d'aquells anys: testimonis de persones afectades -en àudios enregistrats precàriament, pràcticament inaudibles-, alternats i sobreposats amb imatges que ensenyen la magnitud de les obres, les seves venes obertes.

De manera general, contràriament al relat de progrés que envolta la construcció de carreteres, existeix una iconografia figurada que funciona com un "testimonio del dolor de los paisajes y los territorios» (LEPASTIER, 2015: 355). Avui, en el context espanyol, proliferen múltiples formes de militància audiovisual sobre la transformació 
del paisatge i les seves conseqüències. Nación Rotonda documenta l'inventari del canvi d'ús del territori en els darrers quinze anys, mitjançant un projecte col-laboratiu que convida la població a identificar sobre un mapa les aberracions urbanístiques presents a molts pobles i ciutats de la península i les illes. Aquesta cartografia crítica participativa compta amb milers d'entrades que configuren l'arxiu més complet que existeix d'agressions al territori, centrant-se principalment en les carreteres i autopistes abandonades, posant especial èmfasi en les rotondes.

El membres de Nación Rotonda defineixen la pròpia pràctica de la següent manera: «Es una forma de hacer popular una cosa muy técnica como es el urbanismo" (CARRETERO, 2015). Per portar a terme aquesta popularització, principalment utilitzen imatges aèries -que comparen el present i el passat del territori-, les quals evidencien el rastre de la híper-explotació. Aquestes van acompanyades de fotografies de les ubicacions realitzades sobre el mateix terreny, oferint així una altra perspectiva del "cadàver" en qüestió $\mathrm{i}$ apropant el seu aspecte a la gent.

Les possibilitats de col-laboració inaugurades pel context 2.0 permeten la reinvenció subversiva del survey o missió fotogràfica: una forma de representació toponímica, iniciada a finals del segle XIX, que els governs encarregaven per documentar monuments o obres públiques. Per exemple, la Mission Héliographique francesa envià l'any 1851 cinc fotògrafs a captar imatges dels monuments històrics nacionals, atorgant així usos patriòtics a la fotografia pràcticament des dels seus inicis. En contraposició, el survey que proposa Nación Rotonda no és un encàrrec públic, ni molt menys. A partir d'imatges de Google, aportacions individuals i viatges dels membres del col-lectiu, documenta un ampli catàleg de monuments de l'excés i l'abandó.
L'eslògan de Nación Rotonda, irònic, recull una expressió habitual en converses sobre la transformació del territori: «Antes aquí todo era campo». Entre les fites aconseguides, cal destacar la publicació del llibre homònim Nación Rotonda (TRAPIELLO, ALVÁREZ, GARCÍA i TRAPIELLO, 2015) mitjançant una campanya de micromecenatge. Si es necessitaven $8.000 €, 972$ mecenes en van aportar un total de 28.151€.

La circulació en l'esfera mediàtica del motiu visual que ens interessa es vehicula des de fa uns anys a través de les xarxes socials. Anomenarem aquesta forma d'intervenció militant memètica de les ruïnes, perquè persegueix l'objectiu que la iconografia en qüestió, i les conseqüències mediambientals i paisatgístiques associades a la mateixa, esdevinguin virals ${ }^{7}$. A banda de les experiències mencionades fins aquí, altres col-lectius com Terra Ferida han desenvolupat també una pràctica de crítica visual similar a la de Nación Rotonda. El logotip de l'organització mostra Mallorca completament devastada per autovies i carreteres. La metàfora visual no resulta exagerada, ja que, avui, «la superfície requerida per satisfer el dèficit ecològic terrestre seria d'unes 14'7 vegades o 17'7 vegades la superfície terrestre disponible de Balears» (MURRAY, 2012: 2894). És a dir, el nivell de mobilitat actual de les illes requeriria d'un territori 15 vegades superior, 15 arxipèlags.

Terra Ferida participa i impulsa campanyes -juntament amb el Grup d'Ornitologia Balear (GOB) o el monogràfic Tot inclòs (publicat per la Coordinadora Llibertària de Mallorca)- de denúncia del model de desenvolupament balear, basat en la construcció i el turisme. Es tracta d'una organització que, més enllà d'ensenyar les ruïnes, s'ha convertit en un subjecte polític que es confronta amb els incompliments dels programes de partits i administracions. No només documenta i articula 
crítiques artístiques, sinó que obre batalles judicials i convoca mobilitzacions orientades a la justícia social i a la preservació del medi ambient de les illes. Així, la denúncia de Terra Ferida utilitza la visibilització de la destrossa del paisatge com un mitjà per popularitzar, i intentar revertir, la petjada ecològica d'una de les principals súper-potències turístiques del món.

\section{Conclusions}

El fragment de la novel-la En la orilla ha servit per catalitzar un exercici de cinema, televisió i fotografia comparats, sobre el motiu visual de les ruïnes de la crisi immobiliària a la imatge de no ficció. El paisatge després de la batalla resulta una imatge prou suggeridora com per pensar en múltiples figures arruïnades -pobres, endeutats, exiliats, desplaçats-, que assenyalen el paral-lelisme entre guerra i crisi. D'altra banda, els moviments de derrotats per la crisi-com la $\mathrm{PAH}$ - i la militància audiovisual i col-laborativa de diferents col-lectius exemplifiquen diferents maneres d'abordar críticament una situació caracteritzada per un enorme malestar en la població.

D'altra banda, les ruïnes també han estat un objecte d'atenció d'iniciatives vinculades al moviment ecologista. Aquestes han posat en pràctica crítiques visuals a través de la circulació de memes. El paral-lelisme entre l'imaginari de Ballard i les representacions de no ficció posteriors a la crisi permet elaborar una crítica a la ideologia del progrés, centrada en qüestions mediambientals. En aquest sentit, les ruïnes també esdevenen al-legories: el paisatge està ple de talls de navalla, ferides, cicatrius i metàstasis que donen compte, en el pla visual, d'una malaltia: la utilitat de tanta construcció està severament posada en qüestió.

Per totes aquestes raons, resulta apropiat remetre tot plegat a la crítica al capitalisme aportada per Walter Benjamin en diferents escrits. Aquesta funciona com un peu de pàgina a les imatges de les ruïnes de la crisi immobiliària: la perspectiva dels derrotats $i$ de la devastació mediambiental posa en primer pla la necessitat d'un canvi profund de model, en què la sostenibilitat i la garantia del dret a l'habitatge no poden brillar per la seva absència. El motiu visual de les ruïnes resulta, en aquest sentit, un recordatori de la desigualtat i l'abús del medi ambient.

La iconografia de les ruïnes ha generat dues tipologies d'imatges principals: en primer lloc, la fantasmagoria paisatgística, el buit urbà de les imatges a peu de terra, que són les imatges que s'aborden en el primer epígraf; en segon lloc, les imatges aèries, ferides obertes i cicatrius, que es tracten en el segon epígraf de l'article.

A nivell iconogràfic, les ruïnes de la crisi espanyola resulten una part essencial del paisatge del neoliberalisme. Sinònim d'escombraries, d'especulació immobiliària i malaltia de la segona pell; aquest paisatge no té res a veure amb el caràcter sublim de les ruïnes antigues. Més aviat, es tracta de ruïnes quotidianes d'un present en què el valor de canvi està molt per sobre del valor d'ús, amb totes les conseqüències negatives que això comporta. Són ruïnes que evidencien un quadre clínic greu.

Els esquelets d'habitatges buits $i$ la munió de carreteres evoquen, des del seu estatut de no ficció, l'univers ballardià de ciència-ficció catastròfica, però aplicat al present immediat i local:

«Las imágenes más certeras del relato describen carreteras degradadas, [...] supermercados cerrados y coronas de hoteles en sucesivas líneas de mar igualmente abandonados. [...] Al igual que las páginas de Low-Flying Aircraft 
(J. G. Ballard, 1974) el trabajo de Schultz-Dornburg confronta nuestra mirada con las ruinas de una modernidad urbana tan soberbia y totalizante como desfigurada en su propio abandono» (MUÑOZ, 2012: 7-9).

Finalment, les ruïnes també ens parlen sobre la violació de l'article 47 de la Constitució espanyola. Per aquest motiu, no resulta exagerat afirmar que, com a les guerres, quan es declara l'estat d'excepció, part de la carta de drets ha quedat suspesa, si bé no és un conflicte armat el que ha cancel-lat garanties democràtiques com l'habitatge, sinó una altra forma d'excepcionalitat provinent d'un ordre dels mercats.

1/ Seguint la definició del diccionari anglès Collins, per ballardià s'entén: «semblant o que suggereix les condicions descrites a les novel-les de J. G. Ballard, especialment distòpia moderna, desolats paisatges artificials i els efectes psicològics dels canvis tecnològics, socials o mediambientals» (s.d.).

2/ La Sociedad de Gestión de Activos procedentes de la Reestructuración Bancaria (SAREB) és una societat anònima, participada al $55 \%$ per capital públic i $45 \%$ per capital privat, encarregada de la gestió d'actius immobiliaris de quatre entitats bancàries que entraren en fallida.

3/ «Todos los españoles tienen derecho a disfrutar de una vivienda digna y adecuada. Los poderes públicos promoverán las condiciones necesarias y establecerán las normas pertinentes para hacer efectivo este derecho, regulando la utilización del suelo de acuerdo con el interés general para impedir la especulación».

4/ Aquest és el poble valencià imaginari on transcorren la majoria de les novel-les de Chirbes.

5/ La notícia, publicada el 18/06/2005, està citada a FERNÁNDEZ DURÁN, 2006: 1.

6/ Vinyeta publicada a El País, 09/09/2011.

7/ A dia d'avui, el compte de Twitter compta amb més de 19.000 seguidors, que, sumats als més de 10.000 amics de Facebook, fan de les xarxes socials el principal mitjà de comunicació i difusió de les ruïnes de la crisi.

\section{Referències bibliogràfiques}

ARBOLEDA, Pablo; RUINAS MODERNAS et al. (n.d.). "Objetivos de cada colectivo o individuo". Cadáveres inmobiliarios. Recuperat de: $\underline{\text { http:// }}$ cadaveresinmobiliarios.org/objetivos-de-cada-colectivo-o-individuo/ [accés: 9 de novembre de 2018].

ARGULLOL, Rafael (2012). El gran saqueo. SCHULTZ-DORNBURG, Julia, Ruinas modernas. Una topografia del lucro (pp. 71-74). Barcelona: Àmbit.

AUKEN, Margarete (2009). Informe Auken. Aprovat pel Parlament Europeu el 26 de març de 2009.

Ballardian (s.d.). Collins English Dictionary. Recuperat de: https://www. collinsdictionary.com/dictionary/english/ballardian [accés: 3 de febrer de 2019]

BALLÓ, Jordi i BERGALA, Alain (eds.) (2016). Motivos visuales del cine. Barcelona: Galaxia Gutenberg.

BASURAMA (2011). 6000 km. Paisajes después de la batalla. Navarra. Consultable a: www. $6000 \mathrm{~km} .0 \mathrm{rg}$

BENJAMIN, Walter (2013). Libro de los pasajes. Madrid: Akal. 
BRUNAT, David (2017). Las promociones fantasma se pudren en silencio: "Nunca nadie querrá vivir aquí". El Confidencial, 20 de febrer de 2017. Recuperat de: http://www.elconfidencial.com/vivienda/2017-02-20/ promociones-urbanizaciones-fantasma-se-pudren_1331763/ [accés: 5 d'abril de 2017].

CALVO ROY, José Manuel (1997). "Yo soy el milagro”, asegura Aznar al diario estadounidense 'Wall Street Journal'. El País, 21 de maig de 1997. Recuperat de: https://elpais.com/diario/1997/05/21/economia/864165602_850215.html [accés: 5 d'abril de 2018].

CARRETERO, Rodrigo (2015). Nación rotonda: 10 ejemplos de desastres urbanísticos de la crisis (FOTOS ANTES Y DESPUÉS). Huffington Post, 5 d'agost de 2015. Recuperat de: http://www.huffingtonpost.es/2015/06/24/ nacion-rotonda_n_7654460.html [accés: 4 de maig de 2018].

CHIRBES, Rafael (2013). En la orilla. Barcelona: Anagrama.

COSTA, Jordi (dir.) (2008). J.G. Ballard. Autòpsia del nou mil.leni. Barcelona: CCCB/Diputació de Barcelona.

DÍEZ, Anabel (2003). Zapatero culpa al Gobierno de desoír sus avisos sobre el posible estallido de la vivienda. El País. Recuperat de: https://elpais.com/ diario/2003/10/04/espana/1065218417_850215.html [accés: 5 d'abril de 2018].

EL PAÍS (2007). Zapatero garantiza que España está a salvo de la crisis financiera. El País, 4 d'octubre de 2003. Recuperat de: https://elpais.com/ diario/2007/08/22/portada/1187733606_850215.html [accés: 5 d'abril de 2018].

FERNÁNDEZ DURÁN, Ramón (2006). El Tsunami urbanizador español y mundial. Ecologistas en acción. Recuperat de: www.ecologistasenaccion.org/ article.php3?id_article $=4824$ [accés: 5 d'abril de 2018].

FERNÁNDEZ DURÁN, Ramón (2010). Tercera piel. Sociedad de la imagen y conquista del alma. Barcelona:Virus editorial.

GARRIDO, Alejandro (2011). Cabanyal 2011 - Consumo de lugar. Left Hand Rotation - El museo de los desplazados. Recuperat de: http://www. lefthandrotation.com/museodesplazados/ficha_a_garrido.html [accés: 5 d'abril de 2018].

HISPANO, Andrés (2005). Soñando nuestra ruina. MARÍ, Antoni (ed.), El esplendor de la ruina (pp. 173-183). Barcelona: Fundació Caixa Catalunya.

KORCHECK, Kathy (2015). Speculative Ruins: Photographic Interrogations of the Spanish Economic Crisis. Arizona Journal of Hispanic Cultural Studies, Vol. 19, pp. 91-108.

LEAL, José F. (2009). Los diez azotes de Auken al ladrillo español. El Mundo, 26 de març de 2009. Recuperat de: www.elmundo.es/elmundo/2009/03/26/ suvivienda/1238071948.html [accés: 5 d'abril de 2018].

LEPASTIER, Joachim (2016). La cicatriz. BALLÓ, Jordi i BERGALA, Alain (eds.), Motivos visuales del cine (pp. 353-355). Barcelona: Galaxia Gutenberg.

LÖWY, Michael (2003). Walter Benjamin: aviso de incendio. Una lectura de las tesis "Sobre el concepto de historia". Buenos Aires: Fondo de Cultura Económica.

MARÍ, Antoni (2005). El esplendor de la ruina. MARÍ, Antoni (ed.), El esplendor de la ruina (pp. 13-21). Barcelona: Fundació Caixa Catalunya.

MARÍ, Antoni (2016). La ruina. BALLÓ, Jordi i BERGALA, Alain (eds.), Motivos visuales del cine (pp. 214-219). Barcelona: Galaxia Gutenberg.

MUÑOZ, Francesc (2012). Prólogo. SCHULTZ-DORNBURG, Julia, Ruinas 
modernas. Una topografia del lucro (pp. 7-10). Barcelona: Àmbit.

MURRAY, Ivan (2012). Geografies del capitalisme balear: poder, metabolisme socioeconòmic i petjada ecològica d'una superpotència turística, vol. 3. Palma de Mallorca: Universitat de les Illes Balears, Departament de Ciències de la Terra. Recuperat de: http://hdl.handle.net/10803/104203 [accés: 9 de novembre de 2018].

PUNTÍ, Jordi (2012). Arqueología del futuro. SCHULTZ-DORNBURG, Julia, Ruinas modernas. Una topografia del lucro (pp. 117-119). Barcelona: Àmbit.

REDACCIÓN IDEALISTA (2017). El lastre de la vivienda: aún arrastra 1,36 millones de casas vacías en venta por toda España. Idealista, 15 de setembre de 2017. Recuperat de: http://www.idealista.com/news/inmobiliario/ vivienda/2017/09/14/747998-el-lastre-de-la-vivienda-aun-arrastra-1-36millones-de-casas-vacias-en-venta-por [accés: 5 d'abril de 2018].

REYES MATE, Manuel (2006). Medianoche en la historia: Comentarios a las tesis de Walter Benjamin «Sobre el concepto de historia». Madrid: Trotta.

SALIDO COBO, Jorge (2016). La recuperación Inmobiliaria llega a la ciudad de "El Pocero" en Seseña. El Mundo, 22 d'abril de 2016. Recuperat de: http:// www.elmundo.es/economia/2016/04/22/57190cbe468aeb39418b45ee.html [accés: 5 d'abril de 2018].

SCHULTZ-DORNBURG, Julia (2012). Ruinas modernas. Una topografia del lucro. Barcelona: Àmbit.

TRAPIELLO, Guillermo; ÁLVAREZ, Miguel; GARCÍA, Esteban i TRAPIELLO, Rafael. (2015). Nación Rotonda. Madrid: PHREE. 